\section{Rhizosphere Bacterial Population Flux in Golf Course Putting Greens in the Southeastern United States}

\author{
M.L. Elliott ${ }^{1}$ \\ Department of Plant Pathology, Fort Lauderdale Research and Education Center, \\ University of Florida, 3205 College Avenue, Fort Lauderdale, FL 33314
}

E.A. Guertal

Department of Agronomy and Soils, Auburn University, Auburn, AL 36849

H.D. Skipper

Department of Crop and Soil Environmental Science, Clemson University, Clemson, SC 29634

Additional index words. actinomycetes, Agrostis, bacteria, bentgrass, bermudagrass, Cynodon, fluorescent pseudomonads

Abstract. The rhizospheres of creeping bentgrass (Agrostis palustris Huds.) and hybrid bermudagrass (Cynodon dactylon (L.) Pers. $x$ C. transvaalensis Burtt-Davy) putting greens were sampled quarterly for 4 years. Six bacterial groups, including total aerobic bacteria, fluorescent pseudomonads, actinomycetes, Gram-negative bacteria, Gram-positive bacteria, and heat-tolerant bacteria, were enumerated. The putting greens were located in four geographic locations (bentgrass in Alabama and North Carolina; bermudagrass in Florida and South Carolina) and were maintained according to local maintenance practices. Significant effects were observed for sampling date, turfgrass species and location, with most variation due to either turfgrass species or location. Bentgrass roots had significantly greater numbers of fluorescent pseudomonads than bermudagrass roots, while bermudagrass roots had significantly greater numbers of Gram-positive bacteria, actinomycetes and heat-tolerant bacteria. The North Carolina or South Carolina locations always had the greatest number of bacteria in each bacterial group. For most sampling dates in all four locations and both turfgrass species, there was a minimum, per gram dry root, of $10^{7}$ CFUs enumerated on the total aerobic bacterial medium and a minimum of $10^{5}$ CFUs enumerated on the actinomycete bacterial medium. Thus, it appears that in the southeastern U.S. there are large numbers of culturable bacteria in putting green rhizospheres that are relatively stable over time and geographic location.

The soil environment immediately around a plant root, the rhizosphere, frequently has a larger number of microorganisms than soil just a few millimeters away. Rhizosphere bacteria may benefit plants, serving as biocontrol agents or plant growth promoting rhizobacteria (PGPR) (Nijhuis et al.,1993; Raupach and Kloepper, 1998; Schippers et al., 1987; Weller, 1988). There may also be negative effects from rhizosphere bacteria due to growth inhibition or plant disease (Elliott and Lynch, 1985; Schippers et al., 1987; Suslow and Schroth, 1982; Woltz, 1978). A number of reviews are available on the rhizosphere, and on research methods for studying the rhizosphere (Hurst et al., 1997; Kloepper and Beauchamp, 1992; Rovira, 1991). It has been estimated that there are over 2,000 publications on the topic of

Received for publication 28 Oct. 2003. Accepted for publication $20 \mathrm{Feb}$. 2004. Florida Agricultural Expt. Station journal series R-09896. We gratefully acknowledge the technical assistance of E. Des Jardin, J.H. Kim, and K. Xiong, and the cooperation of K. Bibler, M. Pilo, M. Stoddard, and K. Wiles at the Charlotte Country Club and Cougar Point Golf Club. Part of this research was supported by a grant from the United States Golf Association.

${ }^{1}$ To whom reprint requests should be addressed; e-mail melliott@ufl.edu. plant growth (Rovira, 1991).

Research that examines microbial populations associated with turfgrasses encompasses only a very small portion of this large body of work, with the majority having occurred in just the last decade. Of these, a majority of the studies are pest management evaluations, where the effect of a specific bacterial or fungal inoculant on a disease or other pest is evaluated (Hodges et al., 1993; Lo et al., 1997; Nelson and Craft, 1991; Thompson et al., 1996), or the use of general inorganic and organic amendments on a disease is evaluated (Davis and Dernoeden, 2002; Liu et al., 1995). Turfgrass microbial research has also focused on thatch degradation products. Often formulated with some type of bacteria and/or fungi (Berndt et al., 1990; Mancino et al., 1993), the exact content of the materials are often proprietary. Although specific microbes or microbial products may be applied to turfgrass, often data regarding microbial flux as a function of the treatments is not collected, and only secondary indices such as thatch depth or disease control are evaluated. If microbial data is collected, it is usually collected as a bulk soil fraction, or separated into soil and thatch components (e.g., Davis and Dernoeden, 2002; Mancino et al., 1993), and not the rhizosphere component.

Less evident in the turfgrass microbial literature are studies that evaluate microbial populations as affected by common turfgrass management practices. Research has been conducted which examines microbial populations as a function of fungicides (Smiley and Craven, 1979), subsurface aeration and growth regulators (trinexapac-ethyl) (Feng et al., 2002), fumigation (Elliott and Des Jardin, 2001), sand root-zone mixtures (Bigelow et al., 2002; Elliott et al., 2003), and nitrogen amount or sources (Davis and Dernoeden, 2002; Elliott and Des Jardin, 1999a; Elliott et al., 2003; Turner et al., 1985). Again, much of the research examined bacterial populations in the bulk soil component and not specifically in the rhizosphere.

Despite the lack of knowledge regarding bacteria associated with the turfgrass rhizosphere, the commercial marketing of sprayable or irrigation-injected microbial additives for golf course turfgrasses is increasing. Thus, application of microbial products occurs, even though little is known about the background population of microbes that might be affected. Recent studies have indicated that soil bacterial populations stabilize rapidly in newly constructed putting greens planted with hybrid bermudagrass (Elliott and Des Jardin, 2001) or creeping bentgrass (Bigelow et al., 2002). The objective of this research was to expand upon this green-establishment research and examine population fluxes of six different groups of rhizosphere bacteria examined over a 4-year period after the turfgrass was established on the putting greens. Other factors included in this study were geographic location and turfgrass species, with their resulting differences in maintenance practices.

\section{Materials and Methods}

The rhizosphere of two different turfgrass species, bentgrass (Agrostis palustris Huds.) and hybrid bermudagrass (Cynodon dactylon (L.) Pers. x C. transvaalensis Burtt-Davy), were evaluated at four different geographic locations. For each turfgrass, one site was located at an experimental research area at a university where inputs could be controlled, and the other site was located on an actual golf course maintained to meet the golfers' expectations.

\section{Bentgrass sites}

Alabama. In February 1997 miniature putting greens, $1.0 \times 0.5 \times 0.5 \mathrm{~m}$, were constructed at the Auburn University Turfgrass Science Research Unit, Auburn, Ala. The root-zone mix was composed of $80 \%$ quartz sand plus $20 \%$ reed sedge peat, by volume. It had an initial $\mathrm{pH}$ of $6.0,2.27 \%$ organic matter and total porosity of $43.5 \%$. The greens were fumigated on 7 Mar. 1997 using methyl bromide. On 26 Mar. 1997, washed bentgrass sod (A. palustris 'Crenshaw') was planted on each miniature green. The greens were maintained based on maintenance practices common to the area. This included the use 
of small amounts of soluble fertilizer applied weekly, daily mowing at 4-mm height, core aerification every three months, verticutting twice a year, and application of pesticides on an as-needed basis. Nitrogen was applied at $52 \mathrm{~g} \cdot \mathrm{m}^{-2}$ per year using $20 \mathrm{~N}-2.2 \mathrm{P}-8.3 \mathrm{~K}$ and urea $(46 \mathrm{~N}-0 \mathrm{P}-0 \mathrm{~K})$.

North Carolina. Putting greens at the Charlotte Country Club in Charlotte, N.C. were reconstructed in the summer of 1996 . The rootzone mix was composed of $85 \%$ quartz sand plus $15 \%$ Canadian sphagnum peat, by volume. It had an initial $\mathrm{pH}$ of $6.2,0.92 \%$ organic matter and total porosity of $41.5 \%$. The greens were planted with A. palustris 'Crenshaw' seed and maintained based on practices common to the area for maintenance of a private golf course. Nitrogen was applied at $24.5 \mathrm{~g} \cdot \mathrm{m}^{-2}$ per year using urea $(46 \mathrm{~N}-0 \mathrm{P}-0 \mathrm{~K})$, ammonium sulfate $(21 \mathrm{~N}-0 \mathrm{P}-0 \mathrm{~K})$ and diammonium phosphate $(18 \mathrm{~N}-20 \mathrm{P}-0 \mathrm{~K})$, with about $75 \%$ of the nitrogen applied October through April.

\section{Bermudagrass sites}

Florida. Miniature putting greens were constructed at the University of Florida's Fort Lauderdale Research and Education Center. Lerio high-density polyethylene containers, each $0.9-\mathrm{m}$ square and $0.45-\mathrm{m}$ deep, were buried so that the top of the container was level with the surrounding soil. A $15-\mathrm{cm}$ layer of non-calcareous washed river gravel was placed in the bottom of each container. The root-zone mix was composed of $80 \%$ quartz sand and 20\% Canadian sphagnum peat, by volume. It had an initial $\mathrm{pH}$ of $6.5,0.83 \%$ organic matter and total porosity of $42.7 \%$. The greens were fumigated on 15 Mar. 1997 using methyl bromide. Greens were planted with 'Tifdwarf' hybrid bermudagrass sprigs 6 weeks after fumigation. The greens were managed as a new putting green with fertility and water optimized for establishment of the bermudagrass. After establishment, the greens were maintained based on local practices, including mowing six times weekly at $4.7 \mathrm{~mm}$, twice-monthly fertilizer applications, irrigation as needed, and verticutting and topdressing twice a month. Nitrogen was applied at $88 \mathrm{~g} \cdot \mathrm{m}^{-2}$ per year, alternating between $9 \mathrm{~N}-1.3 \mathrm{P}-7.5 \mathrm{~K}$ and $12 \mathrm{~N}-0 \mathrm{P}-0 \mathrm{~K}$ as the fertilizer sources. No pesticides were applied during the experimental period.

South Carolina. Putting greens at the Cougar Point Golf Course on Kiawah Island, S.C. were reconstructed in the summer of 1996. The root-zone mix was composed of $85 \%$ quartz sand plus $15 \%$ Canadian sphagnum peat, by volume, and conformed to U.S. Golf Association specifications. The greens were planted with 'Tifdwarf' hybrid bermudagrass sprigs. For the winter months, the greens were overseeded with Poa trivialis in December of each year. Maintenance practices were those common to the area for maintenance of a private golf course. Nitrogen was applied at $54 \mathrm{~g} \cdot \mathrm{m}^{-2}$ per year using ammonium sulfate $(21 \mathrm{~N}-0 \mathrm{~K}-0 \mathrm{P})$.

Enumeration of rhizosphere bacterial groups. At each site location, four greens were sampled every three months for four years. Initial sampling dates were December
1996 for South Carolina and North Carolina, May 1997 for Alabama, and August 1997 for Florida. Samples were obtained using a 1.0-cmdiameter soil probe to a depth of $10 \mathrm{~cm}$. Ten cores were collected per green, and a sterile razor blade was used to remove green tissue from the top of each core. Cores were put in self-sealing bags and immediately refrigerated or placed on ice for transport. The soil probe was rinsed with an alcohol solution and allowed to air dry between each green sampled. Samples from Alabama were shipped overnight on ice to the University of Florida's Fort Lauderdale Research and Education Center for bacterial enumeration. Samples from North Carolina and South Carolina were transported on ice to Clemson University. Bacterial enumeration was conducted using previously developed techniques (Elliott and Des Jardin, 1999b). All media components were obtained from Difco Laboratories (Detroit, Mich.), Sigma Chemical Comp. (St. Louis, Mo.) or Fisher Scientific (Pittsburgh, Pa.).

In the laboratory, root material was separated from the root-zone mix with manual vigorous shaking and removal of large peat particles. All the root material for each sample, which included closely adhering rhizosphere soil, was placed in a sterile $250-\mathrm{mL}$ flask with either 90 or $95 \mathrm{~mL}$ of sterile diluent $(0.1 \%$ $\mathrm{Na}_{2} \mathrm{P}_{2} \mathrm{O}_{7}$ with $1.0 \%$ glycerol). Flasks with roots were shaken for $30 \mathrm{~min}$ at $200 \mathrm{rpm}$ on a rotary shaker. A 10 -fold dilution series was then completed.

Aliquots $(0.1 \mathrm{~mL})$ of the dilutions were spread plated onto the following media for enumeration (Elliott and Des Jardin, 1999b): a) solidified $10 \%$ tryptic soy broth (10\% TSBA) for total aerobic bacteria; b) S-1 medium for fluorescent pseudomonads; c) humic acid vitamin agar (HAVA), using Fisher humic acid, for actinomycetes; d) azide blood base agar (ABBA) for Gram-positive bacteria (Difco); and e) crystal violet agar (CVA; $10 \%$ TSBA amended with $5 \mu \mathrm{g} \cdot \mathrm{mL}^{-1}$ crystal violet) for Gram-negative bacteria. The dilutions then were placed in an $80{ }^{\circ} \mathrm{C}$ water bath for 10 min, and aliquots spread on $10 \%$ TSBA to enumerate heat-tolerant bacteria. There were two replicate plates for each dilution plated on each medium. The ABBA, CVA and 10\% TSBA were supplemented with $100 \mu \mathrm{g} \cdot \mathrm{mL}^{-1}$ cycloheximide to inhibit fungi.

All plates were incubated at $28^{\circ} \mathrm{C}$ in the dark. After dilutions were completed, dry weight was determined by either filtering flask contents onto filter paper (University of Florida) or picking all root material from the flasks (Clemson University), and then drying material at $80{ }^{\circ} \mathrm{C}$ for $48 \mathrm{~h}$. Bacterial colonies were counted as appropriate for each medium 24 to $48 \mathrm{~h}$ for $\mathrm{S} 1,7 \mathrm{~d}$ for ABBA, CVA and all $10 \%$ TSBA, and $14 \mathrm{~d}$ for HAVA. $\log _{10} \mathrm{CFU}$ (colony forming unit) per gram dry weight of rhizosphere material was then determined.

Statistical analysis. Analysis of variance was performed by the General Linear Models (GLM) procedure (SAS Institute, Cary, N.C.). When appropriate, means were compared using Waller-Duncan $\mathrm{k}$ ratio $t$ test or LSD $t$ test at $P=0.05$.

\section{Results and Discussion}

Analysis of variance of the enumeration data was conducted across all sampling dates for all locations for each bacterial group (Table 1). Significant effects were observed for each group due to date, for four of the six groups due to turfgrass species, and for five of the six groups due to the site location. For all bacterial groups, the sampling date, while significant, accounted for $<10 \%$ of the variation. Turfgrass species was a significant source of variation for all bacterial groups except the Gramnegative bacteria and total aerobic bacteria. The turfgrass species accounted for $<1 \%$ of the variation for Gram-negative bacteria and total aerobic bacteria, $13 \%$ of the variation of the actinomycetes, $33 \%$ of the heat-tolerant bacteria, $66 \%$ of the fluorescent pseudomonads and $89 \%$ of the Gram-positive bacteria. The turfgrass location accounted for $95 \%$ of the variation for Gram-negative bacteria and total aerobic bacteria, $78 \%$ of the actinomycetes, $67 \%$ of the heat-tolerant bacteria, $28 \%$ of the fluorescent pseudomonads, and $<1 \%$ of the variation for Gram-positive bacteria.

Since most variation was due to either the turfgrass species or site location, further comparisons were limited to these two factors. For all bacterial groups enumerated except the Gram-positive bacteria, significantly greater numbers $(P \leq 0.05)$ were associated with either the North Carolina or South Carolina locations (Table 2). There are two possible explanations for this observation. First, these two sites were maintained more intensely as they were actual golf course sites, whereas the Florida and Alabama sites were maintained for research purposes only. This increased maintenance may have influenced the rhizosphere bacterial population. The second possibility concerns sample processing relative to dry weights. One laboratory (Florida) determined the dry weight of all material (roots and soil) remaining in the flasks for the Florida and Alabama locations, while the other laboratory (Clemson) determined the dry weight of only the roots for the North Carolina and South Carolina sites. Therefore, in general, dry weights were lower for the Clemson processed samples, resulting in greater bacterial populations. Despite the variation between laboratories, the standard error for each bacterial population within each laboratory was quite similar (Table 2).

When bacterial populations were compared between turfgrass species across all sampling dates and locations, the bentgrass rhizosphere had significantly $(P \leq 0.05)$ greater numbers of fluorescent pseudomonads than the bermudagrass rhizosphere (Table 3 ). The bermudagrass rhizosphere had significantly greater numbers of Gram-positive bacteria, actinomycetes and heat-tolerant bacteria than the bentgrass rhizosphere. There were no significant differences between the turfgrass species for numbers of Gram-negative and total aerobic bacteria.

While culturing methods only detect a very limited number of the bacteria present in the rhizosphere, these are the bacteria that are considered pests or are often developed for biological control and plant-growth promo- 


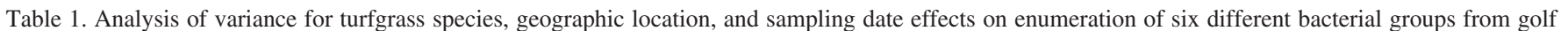
course putting greens.

\begin{tabular}{|c|c|c|c|c|c|c|c|c|c|}
\hline Source & df & Mean square & $P>\mathrm{F}$ & df & Mean square & $P>\mathrm{F}$ & df & Mean square & $P>\mathrm{F}$ \\
\hline & \multicolumn{3}{|c|}{ Fluorescent pseudomonads } & \multicolumn{3}{|c|}{ Gram-positive bacteria } & \multicolumn{3}{|c|}{ Gram-negative bacteria } \\
\hline Sampling date & $\overline{18}$ & 1.295 & 0.0001 & 18 & 2.534 & 0.0001 & 18 & 1.461 & 0.0001 \\
\hline Turfgrass Species & 1 & 17.267 & 0.0001 & 1 & 28.128 & 0.0001 & 1 & 0.189 & 0.2122 \\
\hline Location & 2 & 7.472 & 0.0001 & 2 & 0.233 & 0.7008 & 2 & 32.446 & 0.0001 \\
\hline Error & 207 & 0.186 & --- & 178 & 0.655 & --- & 209 & 0.121 & --- \\
\hline \multirow[t]{2}{*}{ Total } & 228 & --- & --- & 199 & --- & --- & 230 & --- & --- \\
\hline & \multicolumn{3}{|c|}{ Actinomycetes } & \multicolumn{3}{|c|}{ Total aerobic bacteria } & \multicolumn{3}{|c|}{ Heat-tolerant bacteria } \\
\hline Sampling date & 18 & 1.798 & 0.0001 & 18 & 1.177 & 0.0001 & 18 & 0.397 & 0.0001 \\
\hline Turfgrass species & 1 & 3.080 & 0.0003 & 1 & 0.331 & 0.1037 & 1 & 17.608 & 0.0001 \\
\hline Location & 2 & 18.534 & 0.0001 & 2 & 41.436 & 0.0001 & 2 & 35.965 & 0.0001 \\
\hline Error & 201 & 0.226 & -- & 210 & 0.124 & --- & 210 & 0.107 & --- \\
\hline Total & 222 & --- & --- & 231 & --- & --- & 231 & --- & --- \\
\hline
\end{tabular}

Table 2. Mean, standard error and range of rhizosphere bacterial populations across all sampling dates for each location.

\begin{tabular}{|c|c|c|c|c|c|c|c|c|c|c|}
\hline Location & Turfgrass & Mean & SE & Range & Mean & SE & Range & Mean & SE & Range \\
\hline & & \multicolumn{3}{|c|}{ Fluorescent pseudomonads } & \multicolumn{3}{|c|}{ Gram-positive bacteria } & \multicolumn{3}{|c|}{ Gram-negative bacteria } \\
\hline Florida & Bermudagrass & $5.60 \mathrm{c}^{\mathrm{z}}$ & 0.05 & $4.99-6.27$ & $5.12 \mathrm{a}$ & 0.12 & $3.91-5.87$ & $7.26 \mathrm{c}$ & 0.04 & $6.89-7.69$ \\
\hline Alabama & Bentgrass & $6.14 \mathrm{~b}$ & 0.07 & $4.40-6.82$ & $4.43 b$ & 0.10 & $3.26-5.53$ & $7.28 \mathrm{c}$ & 0.05 & $4.71-7.74$ \\
\hline South Carolina & Bermudagrass & $6.22 \mathrm{~b}$ & 0.07 & $5.31-6.99$ & $5.17 \mathrm{a}$ & 0.15 & $1.06-6.91$ & $8.34 \mathrm{~b}$ & 0.06 & $7.65-9.00$ \\
\hline North Carolina & Bentgrass & $6.71 \mathrm{a}$ & 0.07 & $6.08-7.40$ & $4.48 \mathrm{~b}$ & 0.19 & $3.48-6.53$ & $8.55 \mathrm{a}$ & 0.05 & $7.78-9.09$ \\
\hline MSD & & 0.17 & & & 0.34 & & & 0.13 & & \\
\hline \multirow[t]{2}{*}{$P>\mathrm{F}$} & & 0.0001 & & & 0.0001 & & & 0.0001 & & \\
\hline & & \multicolumn{3}{|c|}{ Actinomycetes } & \multicolumn{3}{|c|}{ Total aerobic bacteria } & \multicolumn{3}{|c|}{ Heat-tolerant bacteria } \\
\hline Florida & Bermudagrass & $6.68 \mathrm{c}$ & 0.07 & $5.62-7.23$ & $8.30 \mathrm{~b}$ & 0.04 & $7.92-8.65$ & $6.38 \mathrm{c}$ & 0.04 & $5.85-6.77$ \\
\hline Alabama & Bentgrass & $6.52 \mathrm{c}$ & 0.07 & $4.30-6.94$ & $8.14 \mathrm{c}$ & 0.05 & $5.78-8.46$ & $5.85 \mathrm{~d}$ & 0.04 & $3.86-6.09$ \\
\hline South Carolina & Bermudagrass & $7.53 \mathrm{a}$ & 0.07 & $6.64-8.36$ & $9.47 \mathrm{a}$ & 0.07 & $8.57-10.06$ & $7.51 \mathrm{a}$ & 0.04 & $6.92-7.79$ \\
\hline North Carolina & Bentgrass & $7.23 \mathrm{~b}$ & 0.11 & $5.55-8.61$ & $9.54 \mathrm{a}$ & 0.06 & $9.00-10.11$ & $6.96 \mathrm{~b}$ & 0.06 & $5.89-7.12$ \\
\hline MSD & & 0.20 & & & 0.13 & & & 0.12 & & \\
\hline$P>\mathrm{F}$ & & 0.0001 & & & 0.0001 & & & 0.0001 & & \\
\hline
\end{tabular}

${ }^{2}$ Values are $\log _{10}$ CFU per gram dry root or root and rhizosphere soil. Mean separation within a column by Waller-Duncan k ratio $t$ test, $P=0.05$.

Table 3. Comparison of rhizosphere bacterial populations between turfgrass species, across all sampling dates and locations.

\begin{tabular}{|c|c|c|c|c|c|c|}
\hline Turfgrass & $\begin{array}{c}\text { Fluorescent } \\
\text { pseudomonads }\end{array}$ & $\begin{array}{l}\text { Gram-positive } \\
\text { bacteria }\end{array}$ & $\begin{array}{c}\text { Gram-negative } \\
\text { bacteria }\end{array}$ & Actinomycetes & $\begin{array}{c}\text { Total aerobic } \\
\text { bacteria }\end{array}$ & $\begin{array}{c}\text { Heat-tolerant } \\
\text { bacteria }\end{array}$ \\
\hline Bentgrass & $6.44 \mathrm{a}^{2}$ & $4.48 \mathrm{~b}$ & 7.96 & $6.91 \mathrm{~b}$ & 8.89 & $6.45 \mathrm{~b}$ \\
\hline Bermudagrass & 5.9 & & 7. & $\mathrm{a}$ & 8.9 & $6.98 \mathrm{a}$ \\
\hline LSI & 0.1 & 0.26 & 0.18 & 0.19 & 0. & 0.17 \\
\hline$P>\mathrm{F}$ & 0.0001 & 0.0001 & 0.1801 & 0.0226 & 0.7144 & 0.0001 \\
\hline
\end{tabular}

${ }^{2}$ Values are $\log _{10}$ CFU per gram dry root and/or rhizosphere soil. Mean separation within a column by LSD $t$ test, $P=0.05$.

tion uses (Cook et al., 1996; Lugtenberg and Dekkers, 1999; Nijhuis et al., 1993; Schippers et al., 1995). Examples of culturable genera include: Bacillus and Paenibacillus-sporeforming, heat-tolerant, Gram-positive bacteria; Azospirillum Burkholderia, Enterobacter and Pseudomonas-Gram-negative bacteria; and Nocardia and Streptomyces-actinomycetes. Thus, while representing a small proportion of the total rhizosphere bacteria (less than 10\%) (Alexander, 1999), they are the bacteria of most interest in regards to agricultural, horticultural and turfgrass applications.

For each sampling location, significant differences $(P \leq 0.05)$ were observed in numbers of each bacterial group across sampling dates (data not presented). However, only general trends in population ranges could be established as shown in Fig. 1. For example, for both turfgrass species, the consistently greatest numbers were associated with the total aerobic and Gram-negative bacterial groups, while the least numbers were associated with the Gram-positive bacterial group.
Specific trends regarding time of year with greatest numbers of any bacterial group were also lacking. For example, while there was a distinct drop in all bacterial group numbers at the February 1999 sampling of the bentgrass in Alabama, one year later (February 2000), some of the greatest values were observed for the fluorescent pseudomonads and total aerobic bacterial groups. This could not be attributed to temperature differences as the mean air temperatures were $10.8^{\circ} \mathrm{C}$ and $11.7^{\circ} \mathrm{C}$ in February 1999 and 2000, respectively. On bentgrass grown in North Carolina, the highest fluorescent pseudomonads and Gram-negative bacterial group numbers were in December 1996 and the lowest in December 1998. On bermudagrass in Florida, the least and greatest numbers for the Gram-negative bacteria group were observed in May, with the least in May 1999 and the greatest in May 2000. On bermudagrass in South Carolina, least and greatest numbers for the heat-tolerant bacteria group were observed in September, with the least in September 2000 and greatest in September 1997.
This lack of trends or cycles during the year is probably reflective of the maintenance associated with golf courses, as opposed to pasture grasses or annual grass crops where seasonal trends have been documented (Griffiths et al., 1992; Schnürer et al., 1986). The maintenance goal for a golf course putting green in the southeastern U.S. is a uniform playing surface all year-round. The turfgrass remains in a vegetative state, so there is no cycling between vegetative and reproductive stages. Natural rainfall is supplemented with irrigation to prevent the grass from becoming drought stressed. Since the roots are often $10 \mathrm{~cm}$ or less in length, frequent supplemental irrigation may be required. Putting greens are built to drain rapidly, and are normally composed of at least $80 \%$ to $90 \%$ sand. Thus, water saturation of the soil is minimal. Cyclic effect from nutrition is minimized as small amounts of fertilizer are applied on a frequent basis, from twice a month to once a week. Clippings are collected and removed from the green, which may limit cyclic bacterial degradation activity.

While the basic maintenance practices were similar between the four locations in this study, they were also different. The putting greens sampled in North Carolina and South Carolina were part of an actual golf course. Thus, those greens were managed more intensely and with more variability than those at the university research sites, as the golf course superintendent had to meet the expectations of the golfer. The South Carolina bermudagrass site was over-seeded with a cool-season turfgrass for 

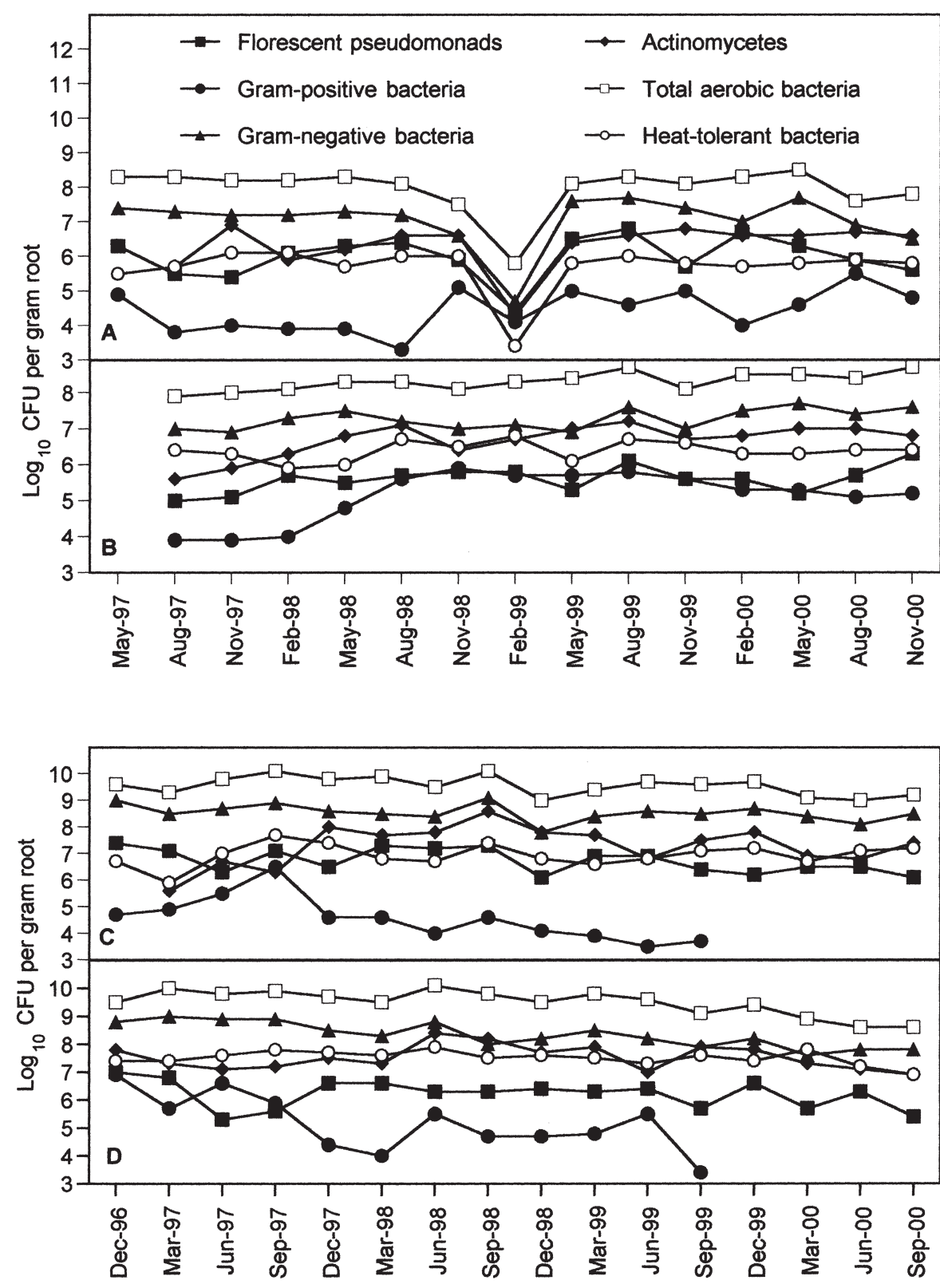

Fig. 1 Populations of six groups of bacteria associated with the rhizosphere of 'Crenshaw' creeping bentgrass in Alabama (A) and North Carolina $(\mathbf{C})$ and 'Tifdwarf' hybrid bermudagrass in Florida $(\mathbf{B})$ and South Carolina (D).

the winter months, a practice that was not followed at the southern Florida location, a semi-tropical climate. Therefore, the March samplings for South Carolina would have been a mixed turfgrass species root sample. No pesticides were applied to the Florida bermudagrass site.

Despite the differences in management, location (both geographic and laboratory assay method) and turfgrass species, the enumeration values for each bacterial group are quite similar at each location. Based on the total aerobic bacterial group data, for most sampling dates in all four locations and both turfgrass species, there was a minimum of $10^{7} \mathrm{CFU}$ s per gram of dry root (Fig. 1). Except for the actinomycetes, bacteria enumerated on $10 \%$ TSBA may also have been enumerated on the other media. Due to their slower growth, actinomycetes are rarely enumerated on the $10 \%$ TSBA medium used to enumerate total aerobic bacteria. Likewise, the actinomycete selective medium (HAVA) minimizes the number of non-actinomycete bacteria that are enumerated on this medium. Therefore, an additional minimum of $10^{5}$ CFUs of actinomycetes were also present in the rhizosphere of these two turfgrass species (Fig. 1).

The data obtained in the current study for bermudagrass in Florida can be directly compared to the values obtained in a previous study of bacteria associated with newly constructed putting greens because the media and techniques used were the same (Elliott and Des Jardin, 2001). The values for all six bacterial groups in both studies are within 0.5 $\log$ units of each other. This indicates that stability is maintained in bermudagrass greens once the bacterial populations stabilize after construction.
The total number of bacteria associated with the bentgrass rhizosphere in Alabama can be compared indirectly with a second study conducted at this site (Feng et al., 2002). In that 1-year study, total numbers of metabolically active bacteria in the bentgrass root zone were determined directly via epifluorescence microscopy. The root zone consistently contained $10^{9}$ cells per gram dry soil. This is two orders of magnitude greater than the values obtained with the indirect plate count method used in the current study, but this is within the range of expectation for differences between the two enumeration methods (Feng et al., 2002). Comparing the current study with a previous study on newly constructed bentgrass greens in North Carolina (Bigelow et al., 2002), values from established greens in the current study tend to be higher, by about one log unit. However, values in the current study for the North Carolina site are for roots only, whereas Bigelow et al. were sampling the bulk soil and removing large roots. One would expect the bulk soil bacterial populations to be less than the rhizosphere soil populations (Elliott and Des Jardin, 2001; Feng et al., 2002).

Stability of soil bacterial communities in established turfgrass also has been demonstrated in a bentgrass fairway study that examined the repeated application of a bacterial biocontrol agent (Sigler et al., 2001). In that study, $10^{6}$ $\mathrm{CFU} / \mathrm{mL}$ of a Pseudomonas aureofaciens strain was applied about 100 times in a 4-month period to a bentgrass fairway. The bacterium did become established in the soil. However, despite these repeated applications, this strain had no impact on rhizosphere or thatch bacterial communities as evaluated with molecular techniques during a 1-year period. The strain did have an impact on the plant canopy bacterial community, albeit on only one member. However, in a 1-year study at the Alabama site using whole-soil fatty acid methyl ester (FAME) profiles, while the total bacterial numbers in the bentgrass root zone did not change, the bacterial community did shift (Feng et al., 2002). A different community was observed in the cool-season months (December through April) than in the warmer summer months (July through September).

One advantage of the dilution plating technique is that one can obtain and store cultures of the strains isolated for future work. About 10,000 isolates from the total aerobic bacterial group from all four sites in this study have been stored and are being identified using gas chromatography analysis of fatty acid methyl esters (GC-FAME). Preliminary results indicate that the dominant genera associated with the bentgrass rhizosphere are Arthrobacter, Bacillus and Pseudomonas, whereas Bacillus and Pseudomonas are the dominant genera associated with the bermudagrass rhizosphere (Skipper et al., unpublished data).

Based on our current knowledge of the bermudagrass and bentgrass root zones, there are large numbers of culturable bacteria present in both the rhizosphere and bulk soil all year. Furthermore, these numbers are relatively stable over time, regardless of maintenance practices and geographic locations. What is 
less clear is the stability of the individual members that form bacterial communities in the rhizosphere (Feng et al., 2002; Sigler et al., 2001). In other words, do the individual bacterial members of this large rhizosphere community change in response to season, location and maintenance practices? For example, is a strain of Bacillus subtilis that is dominant when the turfgrass rhizosphere is first sampled still dominant four years later, or has a second strain of the same species become the dominant member of the bacterial community? Without this information and the knowledge of exactly which organisms are present, what role they have in the root zone, and why they might possibly shift, application of general bacterial inoculants simply to boost culturable bacterial populations in the root zone of established turfgrass may be of little value.

\section{Literature Cited}

Alexander, D.B. 1999. Bacteria and archaea, p. 44-71. In: D.M. Sylvia, J.J. Fuhrmann, P.G. Hartel, and D.A. Zuberer (eds.). Principles and applications of soil microbiology. Prentice Hall, Upper Saddle River, N.J.

Berndt, W.L., P.E. Rieke, and J.M. Vargas, Jr. 1990. Kentucky bluegrass thatch characteristics following application of bio-organic materials. HortScience 25:412-414.

Bigelow, C.A., D.C. Bowman, and A.G. Wollum II. 2002. Characterization of soil microbial population dynamics in newly constructed sand-based rootzones. Crop Sci. 42:1611-1614.

Cook, R.J., W.L. Brucart, J.R. Coulson, M.S. Goettel, R.A. Humer, R.D. Lumsden, J.V. Maddox, M.L. McManus, L. Moore, S.F. Meyer, P.C. Quimby, J.P. Stack, and J.L. Vaughn. 1996. Safety of microorganisms intended for pest and plant disease control: Framework for scientific evaluation. Biol. Control 7:333-351.

Davis, J.G. and P.H. Dernoeden. 2002. Dollar spot severity, tissue nitrogen, and soil microbial activity in bentgrass as influenced by nitrogen source. Crop Sci. 42:480-488.

Elliott, L.F. and J.M. Lynch. 1985. Plant growthinhibitory pseudomonads colonizing winter wheat (Triticum aestivum L.) roots. Plant Soil 84:57-65.

Elliott, M.L. and E.A. Des Jardin. 1999a. Effect of organic nitrogen fertilizers on microbial populations associated with bermudagrass putting greens. Biol. Fert. Soils 28:431-435.

Elliott, M.L. and E.A. Des Jardin. 1999b. Comparison of media and diluents for enumeration of aerobic bacteria from bermuda grass golf course putting greens. J. Microbiol. Methods 34:193-202.

Elliott, M.L. and E.A. Des Jardin. 2001. Fumigation effects on bacterial populations in new golf course bermudagrass putting greens. Soil Biol. Biochem. 33:1841-1849.

Elliott, M.L., E.A. Guertal, E.A. Des Jardin, and H.D. Skipper. 2003. Effect of nitrogen rate and root-zone mix on rhizosphere bacterial populations and root mass in creeping bentgrass putting greens. Biol. Fert. Soils 37:348-354.

Feng, Y., D.M. Stoeckel, E. van Santen, and R.H.Walker. 2002. Effects of subsurface aeration and trinexapac-ethyl application on soil microbial communities in a creeping bentgrass putting green. Biol. Fertil. Soils 36:456-460.

Griffiths, B.S., R. Welschen, J.J.C.M. van Arendonk, and H. Lambers. 1992. The effect of nitrate-nitrogen supply on bacteria and bacterial-feeding fauna in the rhizosphere of different grass species. Oecologia 91:253-259.

Hodges, C.F., D.A. Campbell, and N. Christians. 1993. Evaluation of Streptomyces for biocontrol of Bipolaris sorokiniana and Sclerotinia homoeocarpa on the phylloplane of Poa pratensis. J. Phytopathol. 139:103-109.

Hurst, C.J., G.R. Knudsen, M.J. McInerney, L.D. Stetzenbach, and M.V. Walter (eds.). 1997. Manual of environmental microbiology. ASM Press, Wash., D.C.

Kloepper, J.W. and C.J. Beauchamp. 1992. A review of issues related to measuring colonization of plant roots by bacteria. Can. J. Microbiol. 38:1219-1232.

Liu, L.X., T. Hsiang, K. Carey, and J.L. Eggens. 1995. Microbial populations and suppression of dollar spot disease in creeping bentgrass with inorganic and organic amendments. Plant Dis. 79:144-147.

Lo, C.-T., E.B. Nelson, and G.E. Harmon. 1997. Improved biocontrol efficacy of Trichoderma harzianum 1295-22 for foliar phases of turf diseases by use of spray applications. Plant Dis. 81:1132-1138.

Lugtenberg, B.J.J. and L.C. Dekkers. 1999. What makes Pseudomonas bacteria rhizosphere competent? Environ. Microbiol. 1:9-13.

Mancino, C.F., M. Barakat, and A. Maricic. 1993. Soil and thatch microbial populations in an $80 \%$ sand: $20 \%$ peat creeping bentgrass putting green HortScience 28:189-191.

Nelson, E.B. and C.M. Craft. 1991. Introduction and establishment of strains of Enterobacter cloacae in golf course turf for the biological control of dollar spot. Plant Dis. 75:510-514.

Nijhuis, E.H., M.J. Maat, I.W.E. Zeegers, C. Waalwijk, J.A. van Veen. 1993. Selection of bacteria suitable for introduction into the rhizosphere of grass. Soil Biol. Biochem. 25:885-895.

Raupach, G.S., and J.W. Kloepper. 1998. Mixtures of plant growth-promoting rhizobacteria enhance biological control of multiple cucumber pathogens. Phytopathology 88:1158-1164.

Rovira, A.D. 1991. Rhizosphere research-85 years of progress and frustration, p. 3-13. In: D.S. Keister and P.B. Cregan (eds.). The rhizosphere and plant growth, Kluwer Academic Publ., Boston.

Schippers, B., A.W. Bakker, and P.A.H.M. Bakker. 1987. Interaction of deleterious and beneficial rhizosphere microorganisms and the effect of cropping practices. Annu. Rev. Phytopathol. 25:339-358.

Schippers, B., R.J. Scheffer, B.J.J. Lugtenberg, and P.J. Weisbeck. 1995. Biocoating of seeds with plant growth-promoting rhizobacteria to improve plant establishment. Outlook Agr. 24:179-185.

Schnürer, J., M. Clarholm, and T. Rosswall. 1986. Fungi, bacteria and protozoa in soil from four arable cropping systems. Biol. Fertil. Soils 2:119-126.

Sigler, W.V., C.H. Nakatsu, Z.J. Reicher, and R.F. Turco. 2001. Fate of the biological control agent Pseudomonas aureofaciens TX-1 after application to turfgrass. Appl. Environ. Microbiol. 67:3542-3548.

Smiley, R.W. and M.M. Craven. 1979. Microflora of turfgrass treated with fungicides. Soil Biol. Biochem. 11:349-353.

Suslow, T.V. and M.N. Schroth. 1982. Role of deleterious rhizobacteria as minor pathogens in reducing crop growth. Phytopathology 72:111-115.

Thompson, D.C., B.B. Clarke, and D.Y. Kobayashi. 1996. Evaluation of bacterial antagonists for reduction of summer patch symptoms in kentucky bluegrass. Plant Dis. 80:856-862.

Turner, S.M., E.I. Newman, and R. Campbell. 1985. Microbial population of ryegrass root surfaces: Influence of nitrogen and phosphorus supply. Soil Biol. Biochem. 17:711-715.

Weller, D.M. 1988. Biological control of soilborne plant pathogens in the rhizosphere with bacteria. Annu. Rev. Phytopathol. 26:379-407.

Woltz, S.S. 1978. Nonparsitic plant pathogens. Annu. Rev. Phytopathol. 6:403-30. 